и заболотский < за болотом), напротив, ведет к частичной онимизации данных компонентов.

Березович Е. Л. Местные топонимы в свете деривационной и фразеологической семантики // Язык и прошлое народа : сб. науч. ст. памяти проф. А. К. Матвеева / отв. ред. М. Э. Рут. Екатеринбург, 2012. С. 25-52.

Кривощцапова Ю. А., Феоктистова Л. А. Сравнительные конструкции с личным именем и оттопонимическим прилагательным в костромских говорах // Вестн. Перм. ун-та. Рос. и зарубеж. филология. 2018. Т. 10. Вып. 4. С. 30-42.

Родионова И. В. Характерологические номинации антропонимического происхождения в русских народных говорах // Русский язык в научном освещении. 2005. № 2 (10). С. 159-189.

DOI 10.31168/7996-2700-3.64

\author{
А. М. Кузнецов \\ Даугавпилсский университет \\ Даугавпилс, Латвия \\ anatolijs.kuznecovs@du.lv
}

\title{
К этимологии этнонима латыш
}

Этноним латыш, пожалуй, является единственным из употребляемых ныне в русском языке названий народов, позволяющим различать этническую и государственную принадлежность человека. Существуют наименования латыли и латвиец, соответственно, латылиский — 'относящийся к этносу латыши', а латвийский - 'относящийся к государству Латвия', ср. литовский — 'относящийся к этносу литовцьь и к государству Литва'. В связи с этим возникает вопрос о происхождении слова латыши.

Этноним лотыш впервые зафиксирован в антропонимическом употреблении в записи писца новгородской рукописи «Симоново Евангелие» (или «Симоновское евангелие»), 1270 г. На л. 167г читаем: «писахъ же книгы| сия азъ гюрги с̈нъ попо|въ Гллемаго лотыша съ го|родища» <Писал же эти книги я, Георгий, сын попа, называемого Лотышом, из Городища (под Новгородом. - A. К.)> [Столярова, $2000,123]$. Иногда эту рукопись называли «Евангелием Лотыша», что

(C) Кузнецов А. М., 2019 
неверно, поскольку Лотышиом прозывали не самого писца, а его отца. Согласно комментарию Л. В. Столяровой [2000, 124], «что означает антропоним “Лотыш” - неясно». Он может указывать на этническую принадлежность, но может также обозначать выходца из Латгалии, необязательно латыша.

Хотя указанная запись известна в науке с XIX в., при анализе балтских этнонимов она почему-то не учитывается. Приводятся этнонимы и этнотопонимы Lettos qui proprie dicuntur Lethigalli «латышей, которые собственно называются латгалами» (Х. 3), Letthi vel Letgalli «латыши или латгалы» (X. 3), Henricus de Lettis «Генрик латыш» (XVI. 3) в «Хронике» Генриха Латвийского XIII в.; Lothwa seu Lothihola в «Descriptio Sarmatiarum» Матея (1456-1523); С втьгола (вместо Лътьгола) в Лаврентьевской летописи (л. 2); въ Лотьголоу (1200 г.), Лотыголоу (1228 г.) в Новгородской первой летописи старшего извода [Breidaks, 2007, 540-541]. Отметим также, что рассматриваемый этноним не встречается в качестве антропонима в новгородских берестяных грамотах [Зализняк, 2004, 204].

Трудно признать в этнониме лотыль (совр. латыли) русский гипокористический суффикс ыш-, известный, например, в словах выкормыш, детеныш, найденыши. В современной латвийской прессе было высказано мнение, что латыл - заимствование из нем. Lettisch, но это противоречит древней известности слова в русском языке.

Остается признать слово заимствованным непосредственно из языка древних латгальцев-латышей. Этнонимы обычно используются в форме мн. ч., и от формы lotītis множественное число получало основу на -š- $(<*-t j-)$ : lotǐši, откуда др.-рус. лотылии (в русском языке суффикс -ït(j)- получил форму -ичь, ср. кривичи). От формы мн. ч. далее производится форма ед. ч. лотышь.

Зализняк А. А. Древненовгородский диалект. 2-е изд., перераб. с учетом материала находок 1995-2003 гг. М., 2004.

Столярова Л. В. Свод записей писцов, художников и переплетчиков древнерусских пергаменных кодексов XI-XIV веков. М., 2000.

Breidaks A. Ievads baltu valodniecība. 1. dạ̦a // Breidaks A. Darbu izlase. 1. sējums. Rīga, 2007. S. 483-566. 